\title{
Effect on bone formation of fermented soybeans by combination treatment with high-isoflavone aglycone ratios
}

\author{
Sun-kyung Lee*, You-Seok Lee, Soo-Hyun Ji, Gyeong-Suk Jo, Jeong-Hwa Kang \\ Jellanamdo Agricultural Research and Extension Services, Naju 58213, Korea
}

\section{이소플라본 비배당체 함량을 높인 복합처리 발효콩의 골 형성에 미치는 효과}

\author{
이선경*·이유석·지수현·조경숙·강정화 \\ 전라남도농업기술원 친환경농업연구소
}

\begin{abstract}
The purpose of this study was to investigate the effect on bone formation of fermented soybeans by combination treatment with a high aglycone ratio of isoflavones, since this compounds are known to prevent osteoporosis caused by aging or menopause. The experimental group (osteoporosis-induced rats, $n=20$ ) was divided into four groups, namely the normal group (NC), the OVX group (OVXC), the steamed soybean powder group (SSP), and the fermented soybean powder group (FSP). After 8 weeks of administration, the body weights of the OVX, SSP and FSP groups had increased compared to those of the NC group, while the weight of the uterus had not increased compared to that of $\mathrm{NC}$ group, and the weight of the kidney leaf fat had not decreased compared to that of the OVXC group. In addition, serum levels of alkaline phospatase (ALP) and osteocalcin were not significantly different between the different experimental groups. However numerically, the FSP group appeared to exhibit some effect on bone formation. More specifically, the trabecular bone volume of the femur was significantly increased in the FSP group compared to the OVXC ( $\mathbf{0}<0.01)$, and the trabecular bone mineral density was also significantly increased in the SSP and FSP groups compared to the OVXC group $(\mathbf{p}<0.05)$. These results indicate that fermented soybeans were effective in promoting bone formation in terms of increasing the bone volume and bone density of the femur. The consumption of fermented soybeans could therefore be suggested for the prevention rather than the improvement of osteoporosis.
\end{abstract}

Key words : fermented soybean, bone formation, ovariectomized rats

\section{서 론}

의학의 발달, 건강 중시 트렌드 등에 따라 기대수명이 늘어나면서 전 세계적으로 고령인구가 증가하고 있으며, 미국의 “고령화세계 2015(The Aging World: 2015)" 보고서 에 의하면 2050년 한국의 65세 이상 고령자 비율이 전체 인구의 $35.9 \%$ 로 세계에서 일본(40.1\%) 다음으로 높은 국가

*Corresponding author. E-mail : sklee10@korea.kr Phone : 82-61-330-2514, Fax : 82-61-336-4076

Received 07 November 2019; Revised 02 December 2019; Accepted 10 December 2019.

Copyright (c) The Korean Society of Food Preservation. All rights reserved.
가 될 것으로 전망하고 있다(8). 이러한 고령인구의 증가는 고혈압, 당뇨와 같은 대사성 질환이나 골다공증, 관절염과 같은 퇴행성 질환 등 노인성 질환에 대한 시장 수요가 한층 가속화 될 것으로 전망되고 있으며, 특히 골다공증은 치료 가 어려워 이로 인한 삶의 질을 낮추고 의료비용을 증가시 켜 국민보건의 중요한 문제로 대두되고 있다 $(2,3,17,18)$. 이 는 2015년 건강기능식품 기능성 원료 인정현황에서 빼/관 절 건강에 대한 내용이 29건인 현황을 보더라도 알 수 있다(4).

골다공증(osteoporosis)은 유전적 또는 후천적 요인인 노 화, 폐경, 영양 불균형 등 여러 원인에 의해서 골격 내 무기 질인 골 질량이 감소하여 뼈의 강도를 약화시키고 골절의 위험성이 증가되는 전신적인 골격계 질환이다 $(17,19,22)$. 
세계보건기구(WHO)에 따르면 전 세계적으로 90,700 만 명 의 골다공증 환자가 있고, 골다공증 유병률은 폐경기 이후 의 여성과 노인에게 주로 발생하며, 남성에 비해 여성이 6 배 높게 나타났다고 한다 $(5,6,12,13)$. 이는 폐경기 이후 에 스트로겐 생성의 감소로 조골세포(osteoblast)와 파골세포 (osteoclast)에 영향을 미쳐 골 교체율이 빨라지고 골 흡수가 골 형성보다 높아 골 손실률이 가속화되기 때문이다 $(9,17)$.

현재 골다공증 치료제의 한계점이 드러나기 시작하면서 이를 예방하기 위한 다양한 연구들이 보고되고 있다(10). 골다공증을 예방하기 위해서는 충분한 양의 칼슘 섭취가 중요하나, 칼슘은 우리나라 식생활에서 가장 결핍되기 쉬 운 영양소 중 하나이며 성인의 칼슘 흡수율은 $30 \%$ 이하로 낮다 $(3,14)$. 따라서 칼슘 섭취 외에 에스트로겐 유사물질로 이소플라본 함량이 많은 대두의 골다공증 예방 효과 등 많은 연구가 보고되어 있고, 대두이소플라본의 경우 뼈 건 강에 도움을 주는 건강기능식품 기능성 원료로도 인정되고 있다 $(3,11)$.

이소플라본(isoflavone)은 여성 호르몬인 에스트로겐의 구조 유사체인 식물성 에스트로겐으로, 이의 배당체 (glycoside)와 비배당체(aglycone)의 비율에 따라 생체 내 이용률이 달라진다. 즉, 이소플라본 배당체는 장내 $\beta$ -glucosidase 효소에 의해 당이 가수분해되어 활성형의 비배 당체 형태(aglycone)가 되어 흡수된다 $(4,16,17)$. 특히 콩은 유산균을 이용한 발효과정을 통해 유산균 생성 $\beta$ -glucosidase 효소에 의해 배당체가 감소하고 비배당체가 증가하여 생리활성을 증가시킬 수 있고 비배당체 중 daidzein과 genistein의 생체 내 흡수율이 배당체일 때보다 높다 $(4,16)$.

따라서, 콩의 비배당체 중 daidzein과 genistein 함랑을 높인 복합처리 발효콩을 제조하여 에스트로겐 분비 감소로 인한 제 1 형 골다공증 실험동물 모델의 골 형성에 미치는 효능을 연구하고자 하였다.

\section{재료 및 방법}

\section{실험물질 제조}

본 연구에 사용된 복합처리 발효콩은 농업기술실용화재 단에서 2018년에 수확한 콩(대풍2호 품종)을 구입하여 열 처리, 분쇄, 발효의 3 가지 처리를 통해 제조하였다. 콩을 $180^{\circ} \mathrm{C}$ 에서 20 분 동안 열처리(CBR-101A, Genesis Co., Ltd., Ansan-si, Korea)한 후 분쇄기(DA337, Daesung artlon Co., Ltd, Seoul, Korea)를 이용하여 조분쇄하였다. 여기에 2배수 의 증류수를 넣고 $121^{\circ} \mathrm{C}$ autoclave(JSAT-105, JSR Co., Ltd., Gongju-si, Korea)에서 30 분 동안 증자 후 $37^{\circ} \mathrm{C}$ 까지 냉각하 였다. 증자된 콩에 $0.1 \%$ 의 상업용 유산균 $(\mathrm{CH}-1$ : Lactobacillus delbrueckii subsp. bulgaricus, Streptococcus thermophilus, Jupiter international Co., Ltd; NFM-1: Lactobacillus plantarum, Probioonics Co., Ltd)을 넣고 $37^{\circ} \mathrm{C}$ 인큐베이터(HB-302S-4, Han baek scientific Co., Ltd., Bucheon-si, Korea)에서 72시간 동안 발효하여 복합처리 발 효콩을 제조하였다. 콩은 동결건조(LP 50, ilShinBioBase Co., Ltd., Dongducheon-si, Korea) 후 분쇄하고 생리식염수 에 녹여 실험에 사용하였다. 이렇게 제조한 복합처리 발효 콩은 증자만 한 콩에 비해 이소플라본 비배당체(daidzein+ genistein)의 함량이 약 6.5배 높았다(Fig. 1).

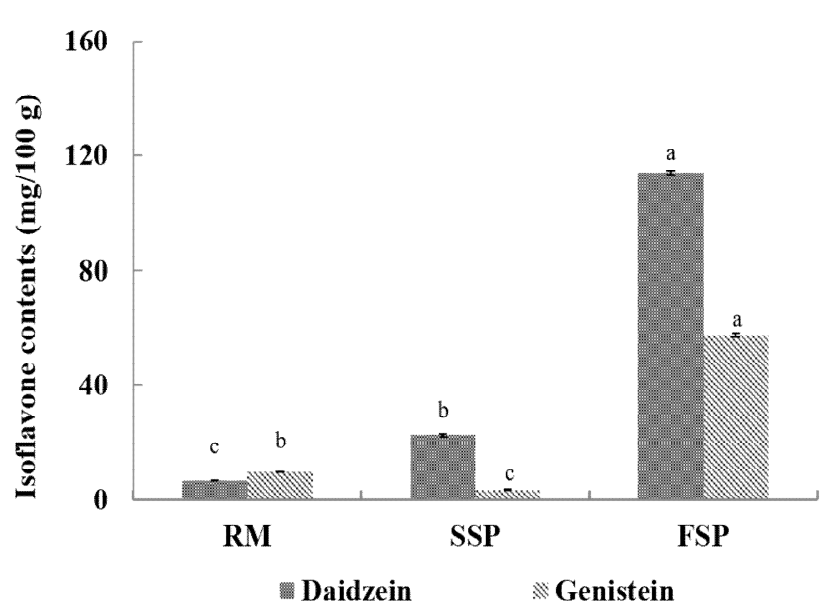

Fig. 1. Comparison of isoflavone contents of soybean fermented with complex processing and soybean without fermentation.

RM: raw materials; SSP: steamed soybean powder; FSP: fermented soybean powder after combination treatment (heat treatment, grinding, and steam). Scale bars represent the mean value $\pm \mathrm{SD}(\mathrm{n}=5)$. Means with different letters above a bar are significantly different at $p<0.05$ by Duncan's multiple range test.

\section{실험동물}

실험동물은 ORIENTBIO에서 공급받은 8 주령(체중 $185 \pm 15 \mathrm{~g}$ )된 Sprague-Dawley (SD) 암컷 rat을 사용하였다. 입수한 실험동물은 7일간의 순화기간 후 임상증상 및 체중 증가에 이상이 없는 개체를 선별 $(\mathrm{n}=20)$ 하여 체중을 맞춘 후 4개의 실험군으로 분리하고, 정상군을 제외한 나머지 군은 난소를 적출하였다. 이후 사육 케이지에 1마리씩 온도 (18-26 $\left.{ }^{\circ} \mathrm{C}\right)$, 습도(30-70\%), 조도(150-300 Lux), 소음 $(45 \mathrm{~dB}$ 이하), 암모니아 농도(20 ppm 이하), 환기횟수(10-15회/시 간), 명암(12시간/일 주기)의 환경에서 사육하며 관리하였 다(GENOSS 실험동물윤리위원회에 의한 승인 : GENIACUC-1903-01).

\section{실험군 설정 및 식이}

4개의 실험군은 난소를 절제하지 않은 정상군(Normal control, $\mathrm{NC}$ ), 난소를 절제 후 아무 처리를 하지 않은 $\mathrm{OVX}$ 군 (Ovariectomized control, OVXC), 난소를 절제 후 증자만 한 콩을 처리한 실험군(steamed soybean powder, SSP), 난소 를 절제 후 복합처리 발효콩을 처리한 실험군(fermented soybean powder, FSP)으로 나누었다. 
실험동물의 사료 식이는 정상군을 제외한 나머지 군에서 골 대사 약화 설정을 위해 calcium free $\operatorname{diet}($ ORIENTBIO), 정상군은 일반 고형사료(Harlan)를 일주일에 2번 $100 \mathrm{~g}$ 씩 배식하여 음수와 함께 자유롭게 먹도록 하였다.

\section{실험군 물질투여}

실험군의 물질 투여는 난소를 적출하여 봉합 후 골 대사 약화 설정을 위한 4 주 이후부터 8 주 동안 먹였고, 생리식염 수에 녹여 $250 \mathrm{mg} / \mathrm{kg}$ 농도의 실험물질은 5 회/주 $(1 \mathrm{~mL} / 100$ g) 경구 투여 하였으며 정상군과 OVX군은 무처리군으로 사료만 급여하였다.

\section{체중 및 조직무게 측정}

실험동물의 체중은 사육 8 주간 주 2 회 측정하였고, 8 주 후 조레틸 $(10 \mu \mathrm{L} / 100 \mathrm{~g}$, Virbac, France)과 럼푼 $(10 \mu \mathrm{L} / 100$ $\mathrm{g}$, Bayer, Germany) 혼합액을 근육 주사하여 마취하고 $\mathrm{CO}_{2}$ 을 이용하여 안락사 시킨 후 자궁, 신장주위 지방을 적출하 여 무게를 측정하였다.

\section{혈중 Alkaline phospatase(ALP) 측정}

Alkaline phospatase의 측정을 위해 난소 적출 8 주 이후 실험동물의 경정맥 채혈을 통해 채취한 혈액은 serum separate tube(Becton Dickinson and Company, USA)에 넣고 튜브를 세운 상태에서 30 분 동안 상온에서 방치 후 $4{ }^{\circ} \mathrm{C}$, $1000 \mathrm{rpm}$ 에서 5 분간 원심 분리하여 혈청을 분리, 취득하였 다.

$\mathrm{ALP}$ 의 측정은 파라니트로페닐 인산염 법 $(p \mathrm{NPP}$, $p$-nitrophenyl phosphate substrate) 을 이용하여 ALP 작용에 의해 p-nitorophenyl phosphate로 분해되어 p-nitrophenol로 유리되는 반응에서 $p$-nitrophenol의 증가속도를 측정하여 $\mathrm{ALP}$ 의 활성치를 구하였다.

\section{혈중 Osteocalcin (OC) 측정}

Osteocalcin의 측정을 위한 혈청은 $\mathrm{ALP}$ 측정 시 필요한 혈청과 동일한 방법으로 취득하였고, 측정은 효소면역측정 법으로 ELSIA kit(Cat no. CSB-E05129r, Cat no. CSBE07866r, CUSABIO, USA)를 이용하였다. 혈청 $100 \mu \mathrm{L}$ 를 채취한 후 $37^{\circ} \mathrm{C}$ 인큐베이터에서 2 시간 동안 배양하고 100 $\mu \mathrm{L}$ Biotin-antibody 넣은 후 $37^{\circ} \mathrm{C}$ 에서 1 시간 배양한 후 세척 (aspirate and wash)을 3회 하였다. 세척 후 $100 \mu \mathrm{L}$ $\mathrm{HRP}$-avidin를 넣고 $37^{\circ} \mathrm{C}$ 에서 1 시간 배양한 후 세척(aspirate and wash)을 5회 진행하였다. 여기에 $90 \mu \mathrm{L} \mathrm{TMB} \mathrm{Substrate}$ 를 분주하여 $37^{\circ} \mathrm{C}$ 에서 $15-30$ 분간 배양하여 색 발현을 진행 하고 Stop solution $90 \mu \mathrm{L}$ 를 넣은 후 5 분 이내로 $450 \mathrm{~nm}$ 흡광도(Synergy HTX, BioTek, USA)에서 측정하였다.

\section{대퇴골의 골부피 및 골밀도}

대퇴골의 골밀도와 골무기질 함량을 측정하기 위해 적출 한 대퇴골을 미세단층촬영기(SkyScan1173;Bruker-microCT, Kartuizersweg 3B 2550 Kontich, Belgium)를 이용하여 측정 하였고 이때 사용된 소프트웨어는 SkyScan1173 control software(Ver 1.6, Bruker-microCT) 이었다. 단면 재구성에 는 Nrecon(Ver 1.7.0.4, Bruker-CT)을 이용하여 이미지 $(2240 \times 2240$ Pixel)를 얻었고, 단면이미지는 Dataviewer (Ver. 1.5.1.2, Bruker-CT)를 이용하여 축을 정렬하였다. 분 석프로그램으로 $\mathrm{Ct}$ Analyzer(Ver. 1.14.4.1, Bruker-CT)를 사용하여 각각 영상에서 골소주와 골수강을 분리하여 trabecular bone volume과 trabecular bone mineral density를 분석하였다.

\section{통계분석}

분석 결과는 모두 3회 반복 측정한 것으로 XLSTAT-Base program(Ver. Perpetual, Addinsoft Inc., NY, USA)을 이용하 여 통계처리 하였다. 실험군간 비교는 일원배치 분산분석 을 실시한 후 $\mathrm{p}<0.05$ 수준에서 Duncan's multiple range test에 의해 평균치 간의 유의성을 검정하였다.

\section{결과 및 고찰}

\section{체중 변화}

폐경이 되어 에스트로겐이 감소하면 이를 보상하기 위해 말초조직에 의해 순환되는 안드로겐의 대사로 에스트라디 올과 에스트론을 합성할 수 있는 체지방이 증가하게 된다고

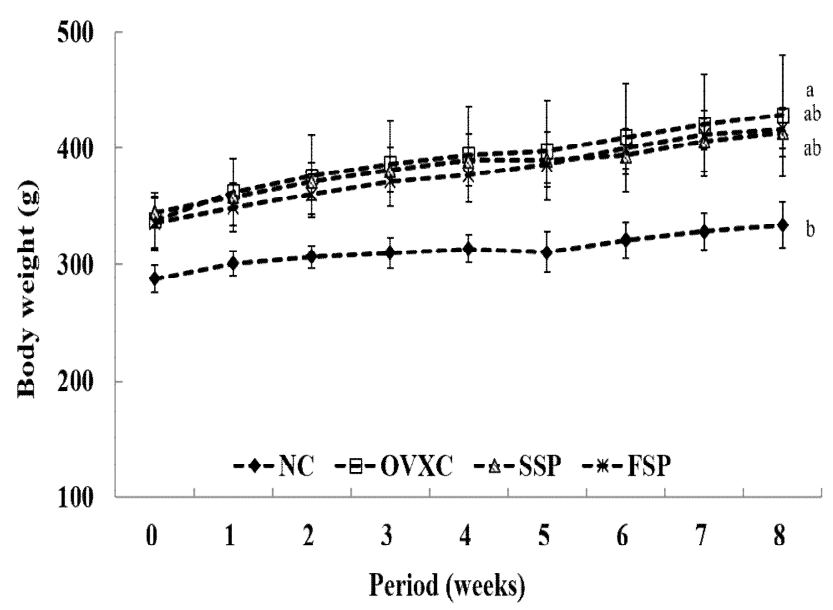

Fig. 2. Changes of body weight in rats for 8 weeks.

NC: nomal control; OVXC: ovarietomized control; SSP: oral administration group of steamed soybean powder; FSP: oral administration group of fermented soybean powder after combination treatment (heat treatment, grinding, and steam). Scale bars represent the mean value $\mathrm{SD}(\mathrm{n}=5)$. Means with different letters above a bar are significantly different at $p<0.05$ by Duncan's multiple range test. 
보고하였다(17,21). 따라서 체지방의 증가로 인한 체중의 증가는 폐경 모델의 중요한 요인으로 실험동물의 난소를 적출 후 8 주의 실험물질 투여기간 동안 rat의 체중 변화를 측정하였다(Fig. 2). 모든 실험군에서 체중이 증가했고, 체 중 증가량이 정상군은 $46 \pm 7.60 \mathrm{~g}, \mathrm{OVX}$ 군은 $90 \pm 28.40 \mathrm{~g}$, $\mathrm{SSP}$ 군는 $69 \pm 9.21 \mathrm{~g}, \mathrm{FSP}$ 군는 $80 \pm 4.88 \mathrm{~g}$ 으로 OVX군에서 체중 증가량이 가장 컸다. 또한 정상군과 $\mathrm{OVX}$ 군은 유의적 인 차이가 있었으나, 실험물질을 투여한 난소 적출군은 정 상군과 OVX군과의 통계적 유의성이 없었다. 이는 청국장 사료의 투여로 골형성능에 효과를 보였으나 체중 증가의 억제는 OVX 대조군과 차이가 없었다는 연구(17)나 난소적 출 후 정상군 대비 체중의 증가 현상을 보인 기존의 연구와 일치하였다 $(21,24)$.

\section{장기무게 변화}

자궁의 무게 변화는 여성 갱년기 개별인정형 인정 과정 에서 시료의 독성 여부를 판단하는 중요한 지표로 설정이 되어있어 rat의 자궁과 신장주위 지방을 적출하여 무게를 측정하고 적출 사진과 함께 나타내었다(Fig. 3, 4). 정상군 대비 난소 적출군의 자궁은 많이 얇아져 있는 것을 확인할 수 있었고 이는 무게를 측정한 결과와도 비슷하였다. 난소 적출군은 정상군에 비하여 무게가 크게 감소하였고 군 간 통계적인 유의성은 없었지만 실험물질을 투여한 군이 OVX군에 비해 더 비대해진 것을 육안으로 확인할 수 있었 다. 이는 난소적출 마우스에서 청국장의 골다공증 효과는 있었으나 자궁 무게는 유의차가 없다는 연구와 일치하였다 (17). 또한 신장주위 지방은 무게를 측정한 결과 정상군과 실험물질 투여 군 간의 통계적 유의성이 있고 실험물질 투여 군 간의 유의차는 없었으나, OVX군과 $\mathrm{FSP}$ 군 간의 유의차도 없었다. 하지만 OVX군에 비하여 FSP군의 크기
가 감소함을 육안으로 확인할 수 있었다. 이 또한 발효 비지 의 난소절제 쥐에서 골밀도 증가 효과가 있었으나 정상군, 난소적출군, 실험물질 투여군의 신장주위 지방 무게의 유 의차가 없다는 연구과 일치하였다(23). 따라서 실험물질의 반복적인 투여로 인한 스트레스로 개체 간의 큰 편차가 무게의 유의성을 나타내지 않았지만 육안으로는 약간의 효과가 있는 것으로 판단되었다.

\section{혈중 ALP 및 Osteocalcin 농도}

Osteocalcin은 뼈의 구조에서 칼슘과 단단하게 결합되는 비타민 $\mathrm{K}$ 의존성 a-carboxy glutamic acid 단백질로써 혈중 농도는 골밀도와 관련이 있고 조골세포에서 분비되며 골 형성 정도를 반영하는 가장 좋은 단일 지표로 보고되었다 (2,9). 또한 혈중 ALP 및 osteocalcin 농도 증가는 젊은 연령 층에서는 골 형성의 증가를 의미하는 긍정적인 면으로 해석 되지만, 폐경 후에는 골 교체율의 증가에 따른 골 소실의 가속화로 골밀도와 음의 상관관계를 가져 골 형성 표지자가 증가한다고 한다(18). 혈중 ALP 농도의 경우, 평균값을 보 면 OVX군과 실험물질 투여군이 차이를 보이고, FSP군은 정상군과 비슷한 결과값을 보였으나, 동물 개체 간 큰 차이 로 인하여 통계적 유의성은 없었다(Fig. 5). 혈중 osteocalcin 농도 또한 정상군과 OVX군은 통계적 유의성을 보였지만 실험물질 투여군 모두 정상군, OVX군과 통계적 유의성을 나타내지 않았다(Fig. 6). 이러한 혈액 내 ALP와 osteocalcin 수치와 같은 결과는 실험물질의 반복적인 투여로 인한 스트 레스 및 대사 문제로 판단되었다. 또한 혈중 $\mathrm{ALP}$ 와 osteocalcin에서 FSP군의 평균값 수치가 SSP군 보다 좀 더 낮고, 정상군과 비슷한 값을 보여 전반적으로 복합처리 발 효콩이 골 형성에 약간의 효과가 있는 것으로 판단되었다.

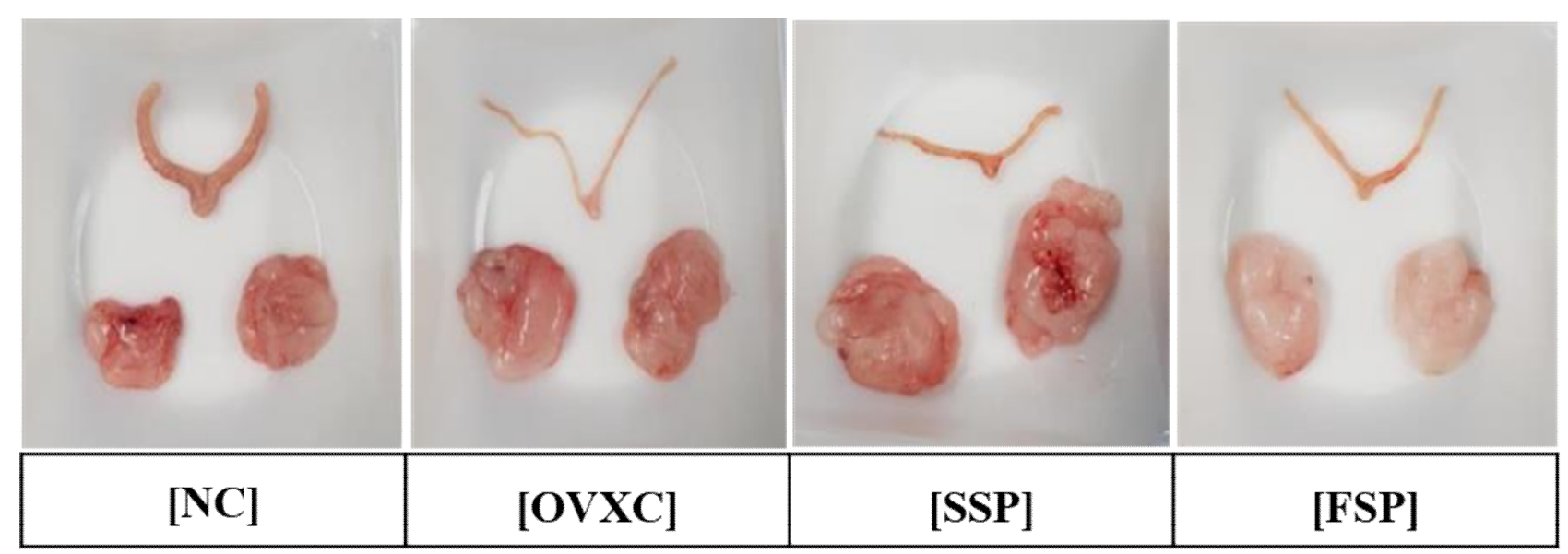

Fig. 3. Picture of uterine and kidney leaf fat in rats to represent the size and shape.

NC: nomal control; OVXC: ovarietomized control; SSP: oral administration group of steamed soybean powder; FSP: oral administration group of fermented soybean powder after combination treatment (heat treatment, grinding, and steam). 
(A)

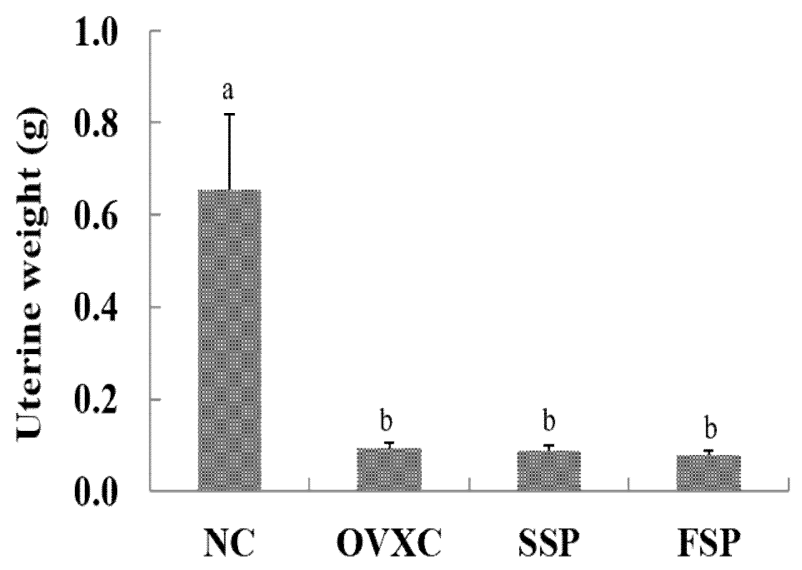

(B)

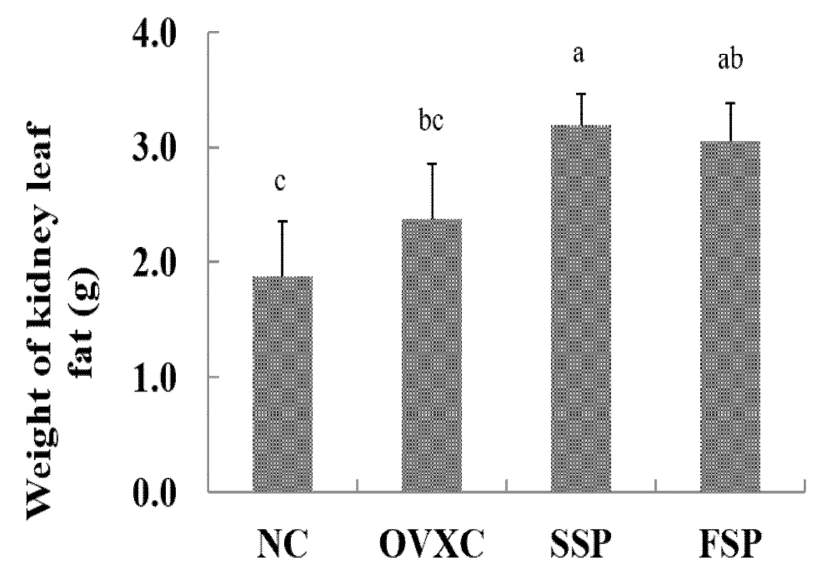

Fig. 4. Uterine weight (A) and kidney leaf fat weight (B) in rats after 8 weeks of treatment with SSP and FSP.

Scale bars represent the mean value $\pm S D(n=5)$. Means with different letters above a bar are significantly different at $\mathrm{p}<0.05$ by Duncan's multiple range test. $\mathrm{NC}$ : nomal control; OVXC: ovarietomized control; SSP: oral administration group of steamed soybean powder; FSP: oral administration group of fermented soybean powder after combination treatment (heat treatment, grinding, and steam).

대퇴골의 골부피 및 골밀도

에스트로겐의 감소로 파골세포의 분화를 억제하는 osteoprotegerin(OPG)가 감소함으로써 골 교체율 균형이 깨 져 골다공증 증상이 나타나는 것으로 골질의 밀도가 낮아지 며 골 감소는 대부분 해면골(trabecular bone)에서 일어난다 고 보고되었다 $(12,17)$. 따라서 해면골 부피와 무기질 밀도 함량 측정은 골다공증 진단에 가장 유용한 지표이다. Rat의 대퇴골(femur)부분 해면골 절단면의 micro-CT 사진을 보면 (Fig. 7), 정상군은 난소를 절제하지 않아 해면골의 밀도가 높았고, 난소를 절제하여 폐경기 모델을 유도한 OVX군은 해면골의 밀도가 상당히 낮아 빈 공간이 많았다. 이는 젤라 틴 효소 분해물의 골대사에 미치는 영향을 측정하기 위한 연구에서 난소 적출군이 정상군에 비해 골밀도의 수치가 감소되었다는 결과와도 일치하였다(20).

또한, OVX군와 대조하여 실험물질을 투여한 군 중 FSP

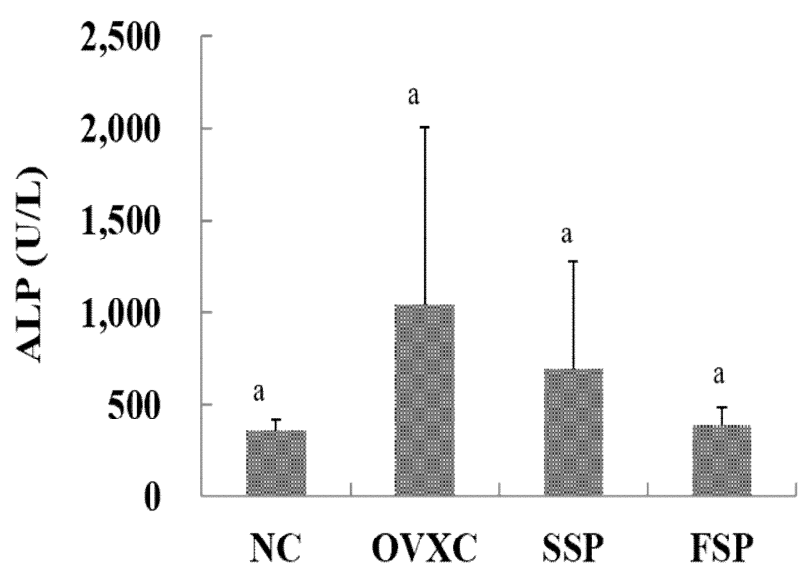

Fig. 5. Serum alkaline phospatase (ALP) levels after 8 weeks of treatment with SSP and FSP.

Scale bars represent the mean value $\pm S D(n=5)$. Means with different letters above a bar are significantly different at $p<0.05$ by Duncan's multiple range test. NC: nomal control; OVXC: ovarietomized control; SSP: oral administration group of steamed soybean powder; FSP: oral administration group of fermented soybean powder after combination treatment (heat treatment, grinding, and steam).

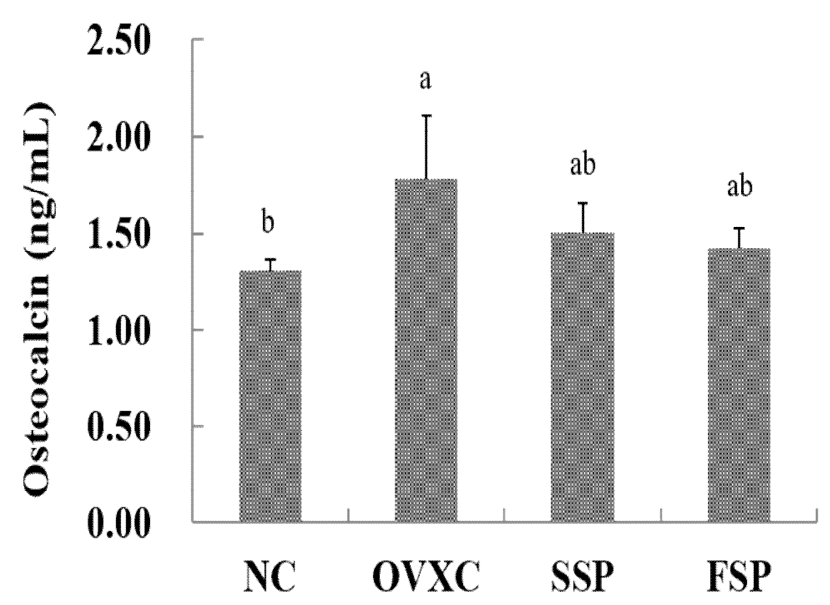

Fig. 6. Serum osteocalcin (OC) levels after 8 weeks of treatment with SSP and FSP.

Scale bars represent the mean value \pm SD $(n=5)$. Means with different letters above a bar are significantly different at $p<0.05$ by Duncan's multiple range test. NC: nomal control; OVXC: ovarietomized control; SSP: oral administration group of steamed soybean powder; FSP: oral administration group of fermented soybean powder after combination treatment (heat treatment, grinding, and steam).

군은 해면골의 밀도가 증가한 것을 육안으로 확인할 수 있었고 이는 골 부피와 골밀도 수치와 유사한 결과를 나타 내었다. 골 부피의 경우, 정상군에 비하여 난소 적출군이 유의적으로 감소하였고 OVX군에 비하여 SSP군은 유의적 인 차이가 없었으나, FSP군은 OVX군과 통계적 유의성 $(\mathrm{p}<0.05)$ 을 나타냈다(Fig. 8). 골밀도의 경우, 정상군에 비하 여 난소 적출군이 유의적으로 골밀도가 감소하였고, $\mathrm{OVX}$ 군에 비하여 SSP군과 FSP군은 $\mathrm{p}<0.05$ 의 유의적 수준에서 차이가 있었으나 SSP군과 $\mathrm{FSP}$ 군 간에는 통계적 유의차가 없었다(Fig. 9). 이는 콩을 발효시킨 청국장이 해면골 감소 를 억제시켜 골다공증을 개선했다는 연구와 일치하는 결과 
Unit: $\mathbf{m m}^{3}$

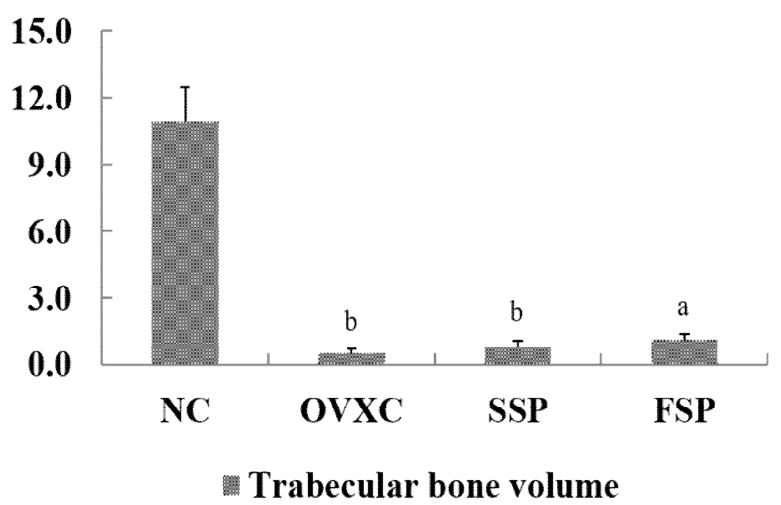

Fig. 8. Value of trabecular bone volume in ovariectomized rats femur.

Scale bars represent the mean value $\pm \mathrm{SD}(\mathrm{n}=5)$. Means with different letters above a bar are significantly different at $p<0.05$ by Duncan's multiple range test of ovarietomized 3 groups.

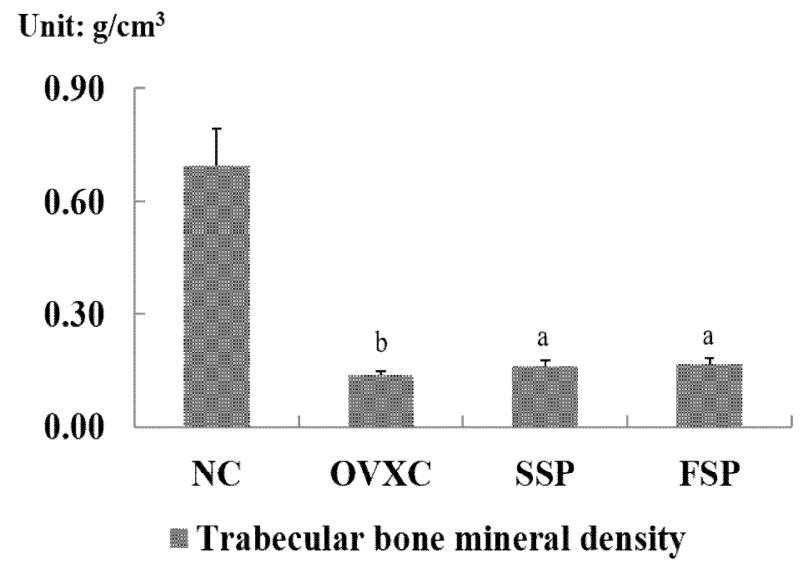

Fig. 9. Value of trabecular bone mineral density in ovariectomized rats femur.

Scale bars represent the mean value $\pm S D(n=5)$. Means with different letters above a bar are significantly different at $p<0.05$ by Duncan's multiple range test of ovarietomized 3 groups. NC: nomal control; OVXC: ovarietomized control; SSP: oral administration group of steamed soybean powder; FSP: oral administration group of fermented soybean powder after combination treatment (heat treatment, grinding, and steam)
였다(17). 따라서 증자한 콩(SSP)은 골 부피를 증가시켰고 복합처리 발효콩(FSP)은 해면골의 부피와 밀도를 증가시 켜 골다공증을 어느 정도 개선시킬 수 있으며, 특히 복합처 리 발효콩이 좀 더 효과적이라고 판단된다.

\section{요 약}

본 연구는 노화 또는 폐경으로 인한 골다공증에 효과가 있는 식물성 에스트로겐인 이소플라본 중 체내 이용률이 높은 비배당체(daidzein과 genistein) 함량을 높인 복합처리 발효콩의 골 형성 효능을 골다공증을 유발한 rat을 통해 확인하고자 실시하였다. 실험군은 정상군 $(\mathrm{NC}), \mathrm{OVX}$ 군 $(\mathrm{OVXC})$, 증자콩 처리군(SSP), 복합처리 발효콩 처리군 (FSP) 4 개 $(\mathrm{n}=20)$ 로 구분하였다. 실험물질 투여 8주 후 OVX 군(90 $\pm 28.40 \mathrm{~g}), \mathrm{SSP}$ 군 $(69 \pm 9.21 \mathrm{~g}), \mathrm{FSP}$ 군 $(80 \pm 4.88 \mathrm{~g})$ 의 체 중은 정상군 $(46 \pm 7.60 \mathrm{~g})$ 에 비하여 증가하였고 난소 적출군 간 유의성은 없었다. 자궁과 신장주위 지방의 무게는 정상 군에 비하여 난소 적출군이 각각 증가하거나 감소하지 않았 고 유의성은 없었으나, SSP군과 FSP군의 약간의 효과가 육안으로 관찰되었다. 혈중 ALP와 osteocalcin 농도는 OVX 군과 실험물질 투여군의 유의성은 없었으나 개체 간 큰 편차로 인한 것으로 수치적으로는 FSP 투여군이 골 형성에 약간의 효과가 있었다. 대퇴골의 골부피는 FSP군이 OVX 군에 비하여 유의적 $(\mathrm{p}<0.01)$ 으로 증가되었고, 골밀도는 OVX군에 비하여 SSP군, FSP군이 $\mathrm{p}<0.05$ 수준에서 유의적 으로 증가되었으며, 실험물질을 투여한 군에서 해면골의 밀도가 증가한 것을 micro-CT를 통해서도 확인할 수 있었 다. 이상의 결과를 통해 복합처리 발효콩을 통한 이소플라 본의 섭취는 골부피와 골밀도를 증가시킬 수 있는 인자로 골 형성에 효과가 있다고 판단되었다. 특히, 난소 적출 후 실험물질을 투여하기 전 4주간의 calcium free 식이로 실험 동물의 골 대사가 너무 약화되어 골 교체율 균형이 이미 심하게 깨진 상태로 그 효과가 미미한 것으로 판단되며,

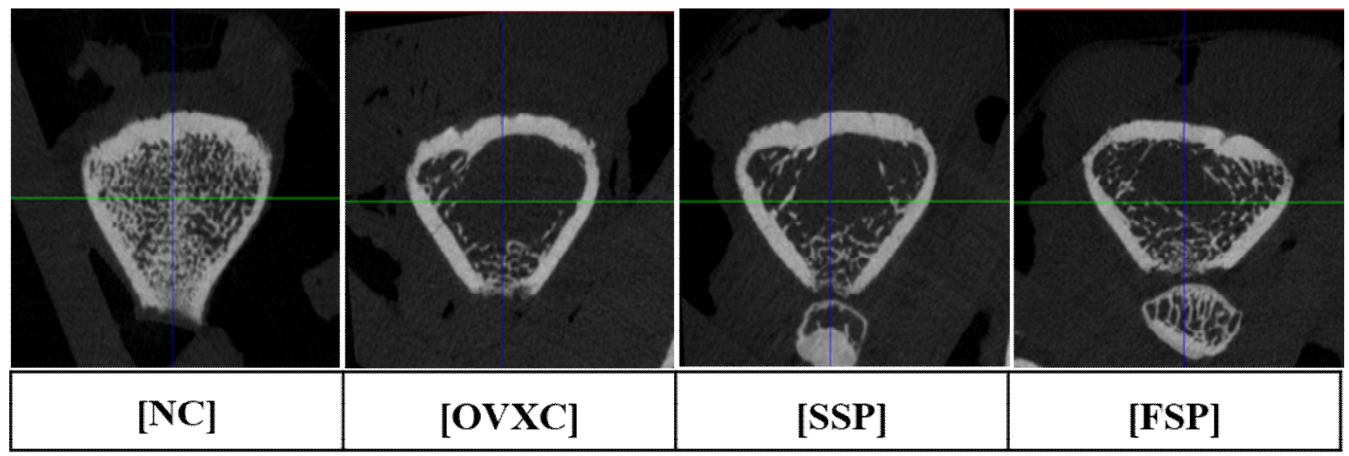

Fig. 7. Micro-CT analysis of the tibia of ovariectomized rats femur.

NC: nomal control; OVXC: ovarietomized control; SSP: oral administration group of steamed soybean powder; FSP: oral administration group of fermented soybean powder after combination treatment (heat treatment, grinding, and steam). 
복합처리 발효콩은 골다공증의 개선 보다 예방을 위하여 섭취하는 것이 더 바람직할 것으로 제안한다.

\section{감사의 글}

본 연구는 지역주력산업육성 기술개발사업(과제명: 지 역 농수산 자원을 활용한 맞춤형 고령친화 유통형 식품 개발, 과제번호: P0002997)의 지원에 의해 수행되었으며, 이에 감사드립니다.

\section{References}

1. Abadjieva DK, Kang SK (1996) Effects of cervi cornu aquaacupuncture on lipid metabolism and osteoporosis in ovariectomized rats. J Korean Orient med, 17, 168-177

2. Angus RM, Sambrook PN, Pockock NA, Eisman JA (1988) Dietary intake and bone mineral density. Bone Mineral, 4, 265-277

3. Ahn HS, Park YS (2004) The correlation of usual dietary isoflavone intake and serum osteocalcin. Korean $\mathbf{J}$ Community Nutr, 9, 38-46

4. KFRI (2017) Study on the bioavailability of tradirional fermented soybean foods. Korea Food Research Institute, Wanju, Korea, p 13-15

5. Burge R, Dawson-Hughes B, Solomon DH, Wong JB, King A, Tosteson A (2007) Incidence and economic burden of osteoporosis-related fractures in the United State, 2005-2025. J Bone Miner Res, 22, p 465-475

6. Jennings LA, Auerbach AD, Maseli J, Pekow PS, Lindenauer PK, Lee SJ (2010) Missed opportunities for osteoporosis treatment in patients hospitalized for hip fracture. J Am Geriatr Soc, 58, 650-657

7. Johnell O, Oden A, De laet C, Garnero P, Delmas PD, Kanis JA (2002) Biochemical indices of bone turnover and the assessment of fracture probability. Osteoporos Int $13,523-526$

8. KAFT (2016) 2016 Processed Food Segment Market: Elderly Foods. Korea Agro-Fisheries \& Food Trade Corporation, Naju, Korea, p 12

9. Kanis JA, Melton LJ, Christiansen C, Johnston CC, Khaltaev N (1994) The diagnosis of osteoporosis. J Bone Miner Res, 9, 1137-1141

10. Kang MJ, Cho JY, Shim BH, Kim DK, Lee J (2009) Bioavailability enhancing activities of natural compounds from medicinal plants. J Med Plant Res, 3, 1204-1211

11. KFDA (2012) Functionality evaluation guide of health functional food: (П)Help for bone / joint health. Korean
Food \& Drug Administration, Sejong, Korea

12. Kim JH, Kim JS (2014) Effects of lycii fructus and lycii folium extracts on osteoporosis in ovariectomized rats. J Korean Soc Food Sci Nutr, 43, 24-29

13. Kim YM, Kim JH, Cho DS (2015) Gender difference in osteoporosis prevalence, awareness and treatment: based on the Korea national health and nutrition examination survey. J korean Acad Nurs, 45, 293-305

14. Louie DS (1996) Calcium and phophorus in health and disease: Intestinal bioavailability and absorption of calcium. CRC Press, Boca Raton, FL, USA, p 45

15. Liu G, Peacock M (1998) Age-related changes in serum undercarboxylated osteocalcin and its relationships with bone density, bone quality, and hip fracture. Calcif Tissue In, 62, 286-289

16. KFRI (2006) Development of functional food materials for prevention of menopause symptom from leguminosae by fermentation process. Korea Food Research Institute, Wanju, Korea, p 16-17

17. Lee MJ, Jung HK, Sim MO, Jang JH, Kim TM, Lee HJ, Lee KH, An BK, Cho JH, Jang MC, Yong JH, Kim JC, Cho HW (2016) Calcium bioavailability and antiosteoporotic effects of Cheonggukjang containing high poly-gamma glutamate contents. J Korean Soc Food Sci Nutr, 45, 1544-1551

18. MOHW (1999) National report of health \& nutrition survey. Ministry of Health and Welfare, Sejong, Korea.

19. Park HM (2010) Current use of drugs for osteoporosis in Korea. Korean J Obstet Gynecol, 53, 152-159

20. Park JE (2011) Effects of gelatin hydrolysates on the bone metabolism in ovariectomized rats. MS Thesis. Konkuk University, Korea

21. Park HJ, Yoon YN, Kim HS (2013) Effects of fermented soybean paste Chungkukjang on the immunoreactivity in ovariectomized mice. J Korean Soc Food Sci Nutr, 42, 1930-1939

22. Walsh CA, Birch MA, Fraser WD, Ginty AF, Gallagher JA (2000) Cytokine expression by cultured osteoblasts from patients with osteoporotic fractures. Int J Exp Path, $81,159-163$

23. Hong GE (2008) Effect of isoflavone aglycon from fermented soy-pulp in preventing osteoporosis for ovariectomized rats. MS Thesis. Konkuk University, Korea

24. Kim GY, Sim KC, Kim GD, Cho GS, Kim KY (2009) The effect of soybean sprouts extract isoflavone on bone related hormones and histological change in the osteoporosis of rats caused by ovariectomy. J Korean Health Fundamental Med Sci 2, p 23-30 